\title{
Kritik Habermas Terhadap Postmodernisme dan Relevansinya bagi Pemahaman Pembangunan
}

\author{
Heru Nugroho
}

Kritik Habermas terhadap Postmodernisme

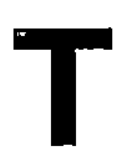

idaklah berlebihan bila keberadaan Juergen Habermas sebagai seorang filosof dan sekaligus ilmuwan sosial diperbandingkan dengan tokoh filsafat jaman klasik Emanuel Khant. Kedua-duanya memperbaharui tilsafat pada masing-masing jamannya dalam tradisi tradisi Jerman. Kalau Kant sebagai pembaharu filsafat pada masanya, yaitu sekitar abad ke 18, maka Habermas juga seorang pembaharu pada masa kini. Perdebatan yang dimasuki oleh Habermas tidak saja terbatas dalam bidang filsafat tetapi melebar ke bidang-bidang lain seperti fenomenologi, bahasa, epistemologi, estetika, sosiologi, psikologi dan lain-lain. Bila dikaitkan dengan faham postmodernisme, Habermas juga terlibat dan mempunyai posisi yang berseberangan dengan faham itu dan layak untuk dibahas dalam rangka mewujudkan diskursus akademik.

Perdebatan yang berkepanjangan antara modernisme dan postmodernisme telah melahirkan dua kubu filsafat. Pertama, adalah kubu yang bermaksud melawan (against) dan melenyapkan keberadaan filsafat modernisme. Kedua, kubu yang berkehendak mengatasi (beyond) sebagai cacat yang disandang oleh modernitas dengan tetap konsisten pada faham itu. Dalam konteks perdebatan ini posisi Habermas adalah yang terakhir. Argumentnya adalah bahwa postmodernisme merupakan refleksi kekecewaan terhadap modernisme itu sendiri sehingga solusinya melarikan diri dari modernitas dengan cara melambaikan tangan terhadap narasi agung. Posisi para penganut postmodernisme oleh habermas diberikan label neo-konservatif, karena telah mencoba meninggalkan sejarah peradaban mereka sendiri. ${ }^{1}$

Menurut beberapa filosof dan ilmuwan sosial, Habermas cukup hati-hati dan bijaksana dalam menghadapi tantangan berdebat dengan mereka yang menganut

'Prinsip Habermas dalam menghadapi merebaknya faham postmodernisme adalah dengan memahami bahwa modernitas tersebut merupakan proses yang tidak atau belum selesai sehingga yang berkembang saat ini adalah kelanjutan dari modernitas. Lihat: Juergen Habermas, Die Moderne ein unvollendetes Projekt, Leipziq: Reclam, 1990, hal. 32-54. 
postmodernisme. Sebagai contoh, ia tidak secara langsung melayani tantangan Lyotard, yaitu salah satu tokoh postmodern yang kondang dari Perancis, namun berupaya memetakan debat antara modern dan postmodern dengan cara mencari akarakar filsafatnya dalam tradisi filsafat Jerman. ${ }^{2}$ Habermas cenderung memetakan pikiran-pikiran filsafat yang dilontarkan oleh para pendahulunya, unutk kemudian memperbaharui pandangan-pandangan tersebut, tetapi ironisnya tidak pernah secara eksplisit memetakan dirinya ada di fihak mana. Bila kita melacak karya-karyanya nampak jelas bahwa yang dipetakan tidak saja postmodernisme tetapi juga modernisme di mana yang terakhir merupakan posisi filsafat kritisnya. Dengan menyimak pemetaan yang dilakukan olehnya akar-akar permasalahan perselisihan tersebut nampak jelas.

Menurut Habermas ada posisi filosofis yang muncul sebagai akibat perselisihan modernisme versus postmodernisme, dua posisi di antaranya saling bertabrakan secara diametral sedang yang satu lebih bersifat ambivalen. ${ }^{3}$ Posisi pertama dinamakan Hegelian sayap kiri. Ini merupakan posisi dari kaum postmodernis yang beranggapan bahwa filsafat pencerahan sudah kehabisan spirit sehingga harus ditinggalkan. Posisi kedua adalah Hegelian sayap pembaharu. Mereka terdiri dari kaum Marxian, Neo-Marxian, hingga mazab Frankfurt. Pandangan ini memiliki keyakinan bahwa modernitas merupakan warisan budaya dan cacat-cacat yang terkandung di dalamnya perlu mendapat pencerahan. Sedang posisi ketiga adalah kaum ambivalen. Posisi ini dipelopori oleh Adomo dan Horkheimer. Pandangan mereka dianggap satu kaki berdiri pada posisi modernisme dan kaki yang lain ikut berlari bersama postmodernisme. Ambivalensi seperti ini berakibat pada kebingungan filo- sofis. Kita tidak akan menjelaskan perselisihan ketiga pandangan tersebut secara mendetail tetapi hanya sekedar memahami bahwa dalam kasus ini posisi Habermas jelas sebagai pendukung modernisme.

Bagi Habermas modernitas adalah suatu proses yang tidak pernah selesai. Oleh karena itu sangat masuk akal kalau dia melontarkan tuduhan bahwa postmodemisme telah memutuskan dirinya sebagai sebuah teori atau pandangan baru sesudah masa modern. Padahal postmodernisme tersebut sama artinya dengan modern itu sendiri, yaitu teori-teori sesudah era Pencerahan (Nack aufklarung). Menurut Habermas ini merupakan pandangan yang bersifat Neo-konsevatif karena secara mendasar berlawanan dengan karya-karya Adomo. Spirit postmodernisme adalah "Die Gegenwart der Vergangenheil"14 yang artinya mengaburkan tradisi kesejarahan dan menganggap bahwa dirinya merupakan sebuah historisme baru. Pandangan seperti ini dapat dianggap a historis.

Untuk alasan itu maka demi memperjelas akar perdebatan telaah historis mengenai pengertian modern perlu diungkapkan secara ringkas dan jelas. Seorang filosof Jauss 5 mengutarakan bahwa istilah "modernus" telah digunakan sejak abad 5. Modernus digunakan sebagai batas sejarah, yaitu antara era Roma yang menyem-

${ }^{2} \mathrm{Hal}$ ini dapat disimak dalam tulisan $\mathrm{F}$. Budi Hardiman, Menuju Masyarakat Komunikatif, Yogyakarta: Kanisius, 1993, hal. 177232.

${ }^{3} \mathrm{~F}$. Budiman, 1993, ibid.

4Juergen Habermas (1990), hal. 32.

${ }^{5} \mathrm{Han}$ Robert Jauss, "Literarische Tradition und gegenwartiges Buwusstsein der Moderne" dalam H.R. Jauss, Litteraturgeschiechte als Provokation, Frankfurt, 1980: 11, diinterpretasikan oleh Habermas (1990), op cit, hal. 33. 
bah berhala (Pagan era) dengan era Kristen yang menyembah Tuhan. Modernitas diartikan sebagai perubahan sosial dengan jalan pintas dari bentuk baru. Juga dalam era Renaisans (abad ke 14-15), istilah modern digunakan untuk menunjuk pada kebangkitan kembali filsafat Yunani kuno. Hal ini juga menunjuk pada sebuah kesadaran dan tindakan baru yang mengacu pada jaman baru Eropa. ${ }^{6}$ Istilah tersebut sering pula dipakai untuk mengartikan masa Pencerahan pada abad ke 17 di Perancis, yaitu sebagai titik awal pembaharu, karena menawarkan hal-hal baru seperti pengetahuan, moral, ilmu, kebudayaan, politik, seni dan lain-lain. Sedang modernisasi dapat diartikan sebagai sebuah proses yang secara bertahap mengucilkan karyakarya klasik, karena modernitas pada hakekatnya menempatkan posisi yang berlawanan-dengan karya klasik, yaitu terjadi Entwrten ${ }^{7}$ untuk hal-hal lama demi terciptanya sesuatu yang baru.

Dua budayawan Baudelaire dan Pae melihat arti modern dari sudut pada seni. Dalam teori seni, istilah modern menunjukkan pada "kesadaran waktu baru" (neu Zeitbewusstsein). Sedang Bergson mengartikan kesadaran waktu baru sebagai orientasi ke depan sehingga terjadi ketidaksinambungan aktivitas keseharian. Pandangan modern menolak "normalisasi tradisi" karena tradisi selalu dalam proses pembentukan. Kesadaran baru dari para seniman ini pada hakekatnya tidak secara absolut bersifat anti sejarah karena mereka hanya menentang penormaan yang salah atau netralisasi aturan yang bersifat menjaga eksistensi tradisi atau historisisme. ${ }^{8}$ Berdasarkan uraian di atas maka Habermas sampai pada hipotesis bahwa era postmodern adalah sama artinya dengan proses menuju masyarakat modern yang belum selesai. ${ }^{9}$ Modernisasi masih meninggalkan sejumlah masalah yang diambil alih oleh postmodren. Jadi faham postmodernisme tidak ubahnya seperti logika dialektika Pencerahan"10 yang secara hakiki menempati posisi yang berlawanan terhadap kerangka politik modernisasi itu sendiri. Dialektika pencerahan tersebut mengacu pada sebuah upaya membebaskan orang dari belenggu penguasaan rasion meskipun dalam kenyataan nalar instrumental sebagai biangkeladi hegemoni justru tetap eksis. Secara konkret dapat dikatakan bahwa telah terjadi permusuhan antara nalar di satu sisi dengan kemerdekaan, kesamaan, dan kebebasan manusia pada sisi lain."

Menuju Masyarakat Komunikatif $\mathrm{Be}$ bas Dominasi: Sebuah Upaya Mencerahi Cacat-cacat Modernitas

Bagi Habermas, pencerahan adalah sebuah filsafat yang memiliki 'semangat membebaskan manusia dari berbagai

${ }^{6}$ Lihat: David Jary \& Julia Jary, Dictionary of Sociology, Glasgow: Herper Collins, 1991, hal. 528.

7/stilah ini sama artinya dengan to devalue atau membuat sesuatu yang lama menjadi tidak bernilai.

aHabermas (1990), op cit, hal. 43-5.

${ }^{9}$ Tesis Habermas untuk menghadapi kaum Neo-Konservatif di Amerika, Jerman, dan Perancis adalah dengan menegaskan bahwa Die Modeme ein unvollendeter Projekt yang artinya moderen adalah proses yang tidak selesai.

${ }^{10} \mathrm{Pengertian}$ lebih lanjut tentang "Djalektika Pencerahan" dapat dilacak dalam Theodor Adorno \& Max Hoekheimer, Dialectic of Enligehtenment. London: Verso, 1979.

${ }^{11 B r y a n}$ S. Turner, "Periodization an Politics of Posmodern" dalam Bryan S. Turner, Theories of Modernity an Posmodernity, London: Sage, 1990, hal. 9-10. 
bentuk dominasi kekuasaan maupun hegemoni kesadaran, yang secara hakiki justru jatuh dalam sebuah dogmatisme baru. Pencerahan yang ingin meningkatkan martabat manusia melalui penggunaan nalar justru jatuh dalam ideologi yang berorientasi teknis. Ideologi ini menjelma dalam bentuk pengejaran atas rasionalitas bertujuan (zweckrationalitaet). Seluruh pertanyaan praktis yang terdapat dalam kehidupan sehari-hari yang tidak dapat dipecahkan secara teknis disebut irrational. Semangat emansipasi yang menjadi landasan filsafat pencerahan telah digantikan oleh instruksi kontrol atas proses-proses yang diobyektifkan. Tingkah laku manusia tidak lagi dianggap subyek penelitian tetapi menjadi obyek yang dapat dimanjpulasi secara teknis atau digunakan sebagai legitimasi teoritik. ${ }^{12}$

Rasionalitas tipe ini menunjuk pada bentuk dan bukan pada isi keputusan yang dirasionalkan tidak memerlukan penalaran dalam pengertian hakiki. Model rasional ini jika diterapkan dalam masyarakat memerlukan sarana administrasi, organisasi dan birokrasi dapat menjebak masyarakat dalam model teknokratik. Kemenangan kesadaran teknokratik baik dalam bidang sosial, ekonomi ataupun politik berarti merupakan kematian bagi model masyarakat liberal yang diwujudkan pada awal abad ke 19. Untuk melawan model teknokratik itu Habermas mengusulkan model "dialectic of potential and will". Model ini mengacu pada sebuah mediasi rasional -ketegangan dialektis- antara kemajuan teknik dan kehidupan sosial yang dapat direalisasikan hanya berdasarkan proses pembuatan keputusan politik melalui diskusi publik yang bebas dari segala bentuk dominasi. Dalam praktek kepusan politik mengalami kerancuan dengan keputusan teknis.

Persyaratan untuk terwujudnya pencerahan dalam masyarakat yang terbebas dari dominasi adalah adanya jaminan formal maupun substansial atas demokrasi. Selain itu harus ada komunikasi permanen -atau ketegangan yang terus-menerusantara ilmu dan opini masyarakat. Contohnya, penemuan di bidang ilmu pengetahuan, dipertimbangkan dengan political relevance, dan diinformasikan kepada public opinion. Informasi balik yang datang dari masyarakat harus diperhitungkan kembali dan menjadi landasan normatif atas keputusan teknis yang akan diambil. Jadi pencerahan dapat direalisasikan melalui terwujudnya "ketidak terbatasan wacana" dari warga masyarakat tentang persoalan-persoalan yang dihadapi. Dengan kata lain keputusan teknis yang dasarnya adalah efisiensi seyogyanya di belakang diskusi publik yang dasarnya berbagai pertimbangan moral, pertimbangan baik-buruk (phroenesis), makna-makna intersubyektif.

Apa yang dilakukan oleh Habermas terhadap praktek-praktek politik pencerahan adalah menentang universalisasi rasionalitas teknis -yaitu reduksi praktis ke teknik atau perluasan purposive-rational actiondalam setiap aspek kehidupan. Emansipasi baru dapat terjadi dalam masyarakat kalau setiap perubahan sosial didasarkan pada pelacakan kembali sejarah umat manusia. Sementara itu emansipasi politik tidak dapat diidentikkan dengan kemajuan teknik karena ada dua pengertian tentang rasionalisasi. Pertama, rasionalisasi dalam dimensi tindakan instrumental berarti pertumbuhan kekuatan-kekuatan produktif dan kontrol teknologis atas kehidupan sosial. Kedua, rasionalisasi dalam dimensi interaksi sosial berarti perluasan komunikasi

12Lihat: Thomas Mc Carthy, The Critical Theoory of Juergen Habermas, London: Polity, 1978, hal. 1-52. 
yang bebas dari segala bentuk dominasi. Dua hal itu, menurut Habermas, melahirkan dua pengertian tindakan, yaitu tindakan rasional dengan maksud instrumental yang dibimbing oleh technical rules dengan tujuan maximzing expected utilities dan tindakan rasional dengan maksud komunikatif yang dibimbing oleh concensual norms. Yang pertama berupaya mencapai goal melalui evaluasi berbagai means yang tersedia, sedang yang kedua didasarkan pada pemahaman intersubyektif dari masing-masing individu. Tujuan dari tindakan purposive-rationaladalah pengejaran goal, namun yang perlu dipertimbangkan adalah tindakan tipe ini harus didefinisikan dan dikejar dalam suatu konteks sosial yang relevan.

Model-ideal tipe masyarakat bebas dominasi menurut Habermas adalah tindakan instrumental yang embedded dalam jaringan kerja interaksi komunikatif. Weber jika membedakan dua tindakan, yaitu tindakan yang berdasarkan pada Zweckrational dan Wertrational. Tindakan purposive-rational dari Habermas mirip dengan Zweckrationamya Weber. Bedanya Habermas sedikit memperluas dalam mana Weber hanya menekankan pada tindakan yang diorientasikan semata-mata pada obyekobyek non-social, sedang Habermas menekankan juga pada penerapan pengetahuan teknis untuk mengontrol tindakan manusia. Apabila tindakan pertama mencoba disembedded dari masyarakat maka yang muncul adalah reifikasi, alienasi, totalitarian dan dominasi. Oleh karena itu konsep tentang kerja seyogyanya harus selalu berakar dalam setiap interaksi sosial dan selain itu harus selalu juga tergantung pada batasbatas kondisi komunikatif (moral dan kebudayaan) suatu masyarakat bersangkutan.

Secara sosiologis, menurut Weber, rasionalisasi adalah proses yang dilembagakan atau merupakan social construc- tion. ${ }^{13}$ Habermas melakukan interpretasikan atas ajaran Weber dengan membedakan dua hal penting. Pertama, the institutional framework of a society yang terdiri dari norma-norma (moral) yang membimbing interaksi sosial. Kedua, subsytem of purposive-rational action yang mengakar dalam masyarakat dan prosesnya dilembagakan oleh sebuah kekuasaan. Dalam masyarakat kapitalis yang terjadi justru sebaliknya, cara produksi kapitalis memperkokoh ekspansi subsistem yang kedua dan menjatuhkan "superioritas" tradisional dari lembaga-lembaga produksi masyarakat. Perubahan masyarakat dari traditional ke modern memerlukan perubahan dalam lembaga legitimasi kekuasaan. Dalam masyarakat traditional legitimasi kekuasaan ada pada kekuatan magis dan agama, sedang pada masyarakat modern legitimasi dibangun melalui kekuatan ilmu pengetahuan dan teknologi. Maka rasionalitas instrumen yang secara teknis telah terbukti kehandalannya dalam era modem menjadi sumber legitimasi kekuasaan.

Pada dasarnya Habermas tidak menentang penerapan rasionalitas teknik dalam masyarakat, tetapi setiap totalisasi rasionalitas teknik dalam setiap aspek kehidupan periu dihindarkan. Caranya adalah dengan reepolitisasi dari berbagai lembaga masyarakat demi terciptanya komunikasi politik yang bebas dari dominasi. ${ }^{14}$ Dengan kata lain, apa yang ingin disimpulkan oleh Habermas adalah bahwa seyogyanya manusia tetap berkaya dengan cara mempertahankan ketegangan dialektis antara pur-

${ }^{13}$ Lihat: Peter L Berger dan Thomas Luckmann, The Social Construction of Reality, London: Penguin Books, 1984.

${ }^{14}$ Walter Reese-Schaefer, Juergen Habermas Einfuenhrungen, Frankfurt: Campus Veriag 1991, hal. 27-36. 
posive-rational action dengan communicative actions. Inilah posisi pencerahan $\mathrm{Ha}-$ bermas, yaitu modernitas yang diaplikasikan dengan revisi bukanya seperti posmodernisme yang menghadapi dengan cara lair dari sejarah.

\section{Habermas dan Problema Pembangunan di Tanah Air}

Berbicara tentang filsafat untuk filsafat atau Habermas untuk Habermas memang sangat mengasyikan, meskipun pada titik tertentu kita sadar bahwa hal itu merupakan suatu fase penelitian dalam upaya mengejar relevansi intelektual. Pada fase yang lain tidak kalah penting diperlukan juga pengejaran relevansi sosial dengan cara menggunakan perspektif kritis. Habermas sebagai kaca mata untuk memahami problema sosial yang aktual. Dalam konteks ini problema pembangunan yang sedang kita hadapi dapat disorot dengan kacamata seperti itu. Ini merupakan suatu upaya untuk melihat manfaat praktis (dalam pengertian kehidupan sehari-hari) teori kritis yang disponsori oleh mazab Frankfurt pada umumnya dan Habermas khususnya.

Pada hakekatnya yang menjadi keprihatinan teori-teori kritik mazab Frankfurt adalah merebaknya rasionalitas instrumen -seperti penerapan efisiensi dan efektivitasdi berbagai bidang kehidupan yang justru membuat manusia mengalami ketidakbebasan dalam pengertian yang sebenarnya. Lalu, apa hubungannya dengan pembangunan nasional yang selama ini dianggap sebagai sarana pembebasan manusia dari kemiskinan? Kata pembangunan telah cenderung menjadi mitos dan mengalami sakralisasi. Arti pembangunan sendiri adalah perubahan sosial dari kondisi tertentu ke kondisi yang lebih baik. Seolaholah tersembunyi "nilai kebaikan" di balik pelaksanaan pembangunan. Karena tujuan dan anggapan dasarnya adalah baik maka proses pembangunan mengijinkan pengorbanan-pengorbanan berbagai dimensi kemanusiaan. Persoalannya adalah nilai yang dianggap baik dalam pembangunan tersebut adalah baik menurut siapa siapa, lapisan mana, dan siapa atau kelompok mana yang harus dikorbankan. Dalam hal ini faham relativitas budaya perlu dipertimbangkan karena baik menurut sekelompok orang belum tentu baik menurut yang lain atau baik pada masa kini belum tentu baik pada masa mendatang.

Kalau pembangunan sendiri mengijinkan pengorbanan -yaitu demi pembangunan maka muncul berbagai bentuk penggusuran secara paksa -maka proses tersebut sedang mengalami kontraksi dengan substansi nilai yang terkandung dalam konsep pembangunan itu sendiri, yaitu pembebasan manusia. Di balik logika pembangunan yang seperti itu adalah rasionalitas instrumen: Seluruh mekanisme pembangunan diarahkan pada pengejaran terhadap target-target tertentu yang dasarnya adalah efisiensi, efektivitas dan nilai tambah di mana pengejaran itu kadang-kadang mengorbankan nilai-nilai kemanusiaan seperti intensitas komunikasi politik dan demokrasi sosial. Demi pertumbuhan ekonomi maka stabilitas politik atau depolitisasi merupakan syarat mutlak hingga kontradiksinya adalah bahwa pembangunan sendiri justru semakin menjauhkan masyarakat dari demokrasi dan kebebasan politik.

Proses pemberangsuran aspirasi politik warga marginal yang oleh teoritis kritis sering dinamakan "patologi pembangunan", telah ikut mewarnai jalannya pembangunan itu sendiri. Pembangunan yang tujuannya merubah kondisi sosial menjadi lebih baik yang dilaksanakan dengan cara "pemberdayaan ekonomi", ironisnya cenderung menciptakan "ketidakberdayaan politis" masyarakat lapisan tertentu. Terjadi kontra- 
diksi dalam cita-cita masyarakat bebas dominatif ala Habermas, yaitu tidak terjadi ketegangan dialektis antara rasionalitas instrumen dan komunikatif, tetapi yang pertama teiah meniadakan yang kedua. Dengan kata lain, menurut istilah kaum eksistensialis, pembangunan hanya sekedar membebaskan masyarakat dari (freedom from) kondisi kemiskinan ekonomi tetapi tidak membebaskan masyarakat untuk (freedom to) kondisi politik yang tanpa dominasi atau demokratis.

Birokrasi yang menjadi instrumen politis penggerak roda pembangunan ironisnya justru cenderung tercerabut dari masyarakat dan berlakunya bersifat diterminan terhadap setiap warga masyarakat. Padahal birokrasi dalam negara liberal justru mengakar dalam masyarakatnya dan bersifat melayani setiap warga masyarakat yang membutuhkan. Ini bisa terjadi karena ada proses dialektis antara birokrasi yang menyembunyikan rasionalitas instrumen dengan sistem politik dan moral masyrakat yang liberal. dan demokratis. Karena iklim politis yang demokratis maka birokrasi yang tujuannya adalah mengejar target-target efisiensi dan efektivitas eksistensinya berada di belakang kesepakatan "politis" masyarakat itu sendiri. Diskusi publik merupakan landasan beroperasinya birokrasi, atau dengan kata lain justru tujuan diselenggarakannya birokrasi adalah mengejar target-target yang telah disepakati oleh mekanisme diskusi publik itu. Bukan sebaliknya, diskusi publik dikorbankan dan dianggap tidak efisien demi mengejar target pertumbuhan ekonomi. Meskipun masyarakat bebas dominasi merupakan sebuah tipe ideal yang dikonstruksikan oleh habermas namun setiap praktek politik yang mengarah ke konsep itu perlu diteladani.

Kenyataan yang masih memprihatinkan adalah bahwa cita-cita Habermas tersebut kadang-kadang menjadi utopia ketika kita melihat persoalan secara konkret di tanah air. Diskusi publik yang sebetulnya merupakan warisan sistem politik Yunani -yaitu kehidupan dalam masyarakat Polis di mana demokrasi bersifat langsungtidak terjadi dalam proses pembangunan. Idealnya keputusan teknis, misal keputusan untuk membangun reaktor nuklir Muria untuk pembangkit listrik, harus berada di belakang diskusi publik. Dalam proses pembangunan yang mengalami distorsi instrumental, ruang publik telah diintervensi oleh kekuatan politis negara sehingga opini publik yang muncul adalah bukan opini masyarakat tetapi justru opini elit politik atau negara.

Akibat dari dominasi raung publik oleh negara adalah adanya kecenderungan keputusan teknis bukan didasarkan atas diskusi dan opini publik tetapi didasarkan pada keputusan elit politik yang dipaksakan ke dalam masyarakat luas. Melalui mekanisme birokrasi, administrasi, media massa yang terbelenggu dan aparatus yang memiliki wewenang untuk memaksakan kekuatan fisik terciptalah "stabilitas politik". kemudian opini elit yang telah dipersiapkan tersebut ditransfer ke ruang publik sehingga seolah-olah menjadi opini publik. Kalau hal ini benar maka bisa jadi pengambilan keputusan untuk membangun instalasi nuklir Muria atau proyek-proyek industri yang lain lebih didasarkan pada kepentingan elit politik dari pada kepentingan masyarakat luas. Ini merupakan "sisi gelap" dari pembangunan dan perlu mendapat pencerahan dengan cara mewujudkan political empowerment sehingga mekanisme demkorasi dan diskusi publik dapat ditegakkan. Opini publik yang tumbuh dalam arti substansial dapat dipakai sebagai sarana kontrol atas jalannya pembangunan atau bahkan kekuatan atas kontrol kekuasaan pembangunan sehingga meng- 
hindarkan masyarakat dari berbagai bentuk dominasi.

Mengejar "nilai tambah" dengan sarana ilmu pengetahuan dan teknologi pada hakekatnya bukan hal yang ditabukan baik dari sisi moral maupun sisi politis. Yang menjadi persoalan adalah bagaimana bentuk mekanisme politik yang digunakan dalam rangka mengejar target nilai tambah tersebut? Apabila dalam mengejar nilai tambah itu justru mengakibatkan ketidakberdayaan manusia, yaitu kebebasan manusia dari berbagai dimensi. Banyak ahli atau teknokrat yang beranggapan bahwa untuk menghadapi persaingan pasar dunia perlu meningkatkan nilai tambah produksi kita. Nilai tambah ini akan dapat terwujud kalau kita mempunyai teknologi tinggi sehingga produk-produk kita dapat bersaing di pasar internasional. Untuk itu diperlukan pembudayaan ilmu pengetahuan dan teknologi. Pertanyaan tersebut tidak salah tetapi cara mengejarnya yang perlu diperhatikan.

Dalam rangka mewujudkan tujuan itu diperlukan sistem kelembagaan instrumentalis, yaitu sistem pendidikan harus menyesuaikan permintaan kompetisi pasar yang sedang terjadi. Kebijakan seperti ini sering dinamakan link and match. Sistem pendidikan diarahkan hanya sekedar mewujudkan orang trampil dalam menguasai ilmu pengetahuan dan teknologi tetapi tidak mengerti persoalan poltiik. Sistem pendidikan seperti ini cenderung sekedar menciptakan robot-robot yang peka terhadap persoalan dan instruksi teknis tetapi cenderung bebas terhadap masalah-masalah moral. Tentunya model pembangunan seperti ini bersifat tidak membuat siswa berdaya tetapi justru merupakan perwujudan dominasi jaman baru karena para siswa dipaksa menginternalisasi logika sistem yang instrumental dan teknis tersebut. Para siswa menjadi tidak punya imaginasi sosiologis dalam rangka mengaktualisa- sikan alternatif-alternatif di luar sistem yang barangkali lebih baik dari pada alternatif-alternatif yang ditawarkan oleh sistem yang eksis. Bisa jadi ini merupakan dialektika pencerahan yang telah diramalkan oleh Adorno dan Horkheimer beberapa dasawarsa lalu. ${ }^{15}$ Bahkan Marcuse menyebut sebagai gejala "desublimasi represif". ${ }^{16}$

Kita seyogyanya belajar dari negara industri maju bukan hanya dari satu sisi (kemajuan ekonomi dan teknologi) tetapi juga sisi lain, yaitu kegetiran-kegetiran sosial dan politik ketika negara itu memasuki masa pembangunannya hingga fáse kapasitas akhir. Kita seyogyanya disamping berorientasi instrumental juga memahami perjalanan sejarah manusia secara universal. IImu pengetahuan dan teknologi memang merupakan sarana untuk mengejar kemajuan ekonomi dan hal ini tidak akan ada orang yang membantahnya. Namun pengorbanan bidang politik dalam rangka membudayakan ilmu dan teknologi dapat diharamkan secara moral. Eksistensi ilmu pengetahuan dan teknologi tetap harus diletakkan dibelakang moral. Kita bukan harus berteknologi tetapi kita perlu berteknologi sejauh teknologi tersebut bermanfaat dan ada hubungannya dengan proses pembebasan manusia dari ketertindasan berbagai hal.

Kemajuan sebuah peradaban manusia bersifat relatif dan tidak sekedar dilihat dari kamajuan ilmu dan teknologinya tetapi juga dari perkembangan filsafat, sastra, humaniora dan moral. Dengan kata lain kemajuan teknis tidak selalu berarti kemajuan kebudayaan, sebab dapat saja yang terjadi adalah kemajuan teknis tetapi disertai

${ }^{15}$ Adorno dan Horkheimer (1979), ibid. ${ }^{16}$ Herbert Maercuse, One-Dimensional Man, Boston: Beacon, 1964. 
dengan kemunduran budaya politik. Tidak jarang kemajuan teknis disertai dengan sifat apolitis masyarakat karena sistem politik yang dipakai untuk mengejar nilai tambah tersebut berwajah beku atau depolitis.

Pada hakekatnya kelemahan atau ketertinggalan yang sifatnya teknis dapat dikejar dengan relatif cepat (barangkali satu periode PJPT kita sudah dapat mewujudkan industri pesawat dan komputer), tetapi yang perlu diwaspadai adalah bahwa kerusakan budaya (khususnya budaya berpolitik) tidak akan dapat diperbaiki hanya dalam waktu pendek karena memerlukan pelembagaan dalam kesadaran. Dengan kata lain pembangunan ekonomi dapat diwujudkan dalam waktu relatif singkat tetapi pembangunan politik memerlukan waktu beberapa generasi. Contoh: demokratisasi di tingkat orang bawah (grass róof) kadang sulit dijalankan karena trauma masa lalu, yaitu tekanan-tekanan politis oleh rezim, yang dialami oleh masyarakat yang bersangkutan. Sehingga ketika iklim politis mulai agak terbuka para "wong cilik" tatap saja merasa tidak bebas dan kurang mampu bersuara, dalam struktur politik yang ada.
Untuk itulah maka perspektif habermas ini dapat dipakai sehingga referensi untuk melihat problema pembangunan. Pembangunan yang membebaskan manusia (baik dari segi ekonomi dan politik) bukanlah sesuatu yang mustahil direalisasikan, tetapi perwujudannya memerlukan persyaratan normatif. Pembangunan agar tidak terjebak dalam dialektika (patologi masyarakat) memerlukan persyarakatan normatif, yaitu adanya proses dialektis antara pengejaran target ekonomi (efisiensi dan efektivitas atau pertumbuhan ekonomi) dengan nilai-nilai moral dan semuanya ini harus diletakkan dalam sistem politik yang demokratis. Secara konkret jaminan demokrasi itu salah satunya dapat berupa kebebasan berfikir secara kritis dan melakukan tindakan kritik terhadap pembangunan karena aktivitas kritik bukan berarti bersifat anarkhis tetapi justru hasrat untuk mencari kebenaran (Wahrheif). Selain itu juga tercipta diskusi publik yang tidak terbatas dalam rangka memecahkan persoalan kemasyarakatan. Ketegangan dialektis yang permanen akan selalu tercipta antara para pengambil kebijakan (penguasa), teknokrat, dan opini publik demi terwujudnya kontrol sosial dari masing-masing fihak. 